The Canadian Mineralogist

Vol. 42, pp. 1159-1168 (2004)

\title{
EXTREME COMPOSITIONAL VARIATION OF PYROCHLORE-GROUP MINERALS AT THE OKA CARBONATITE COMPLEX, QUEBEC: EVIDENCE OF MAGMA MIXING?
}

\author{
SHANNON E. ZUREVINSKI ${ }^{\S}$ AND RogER H. MITCHELL ${ }^{\S}$ \\ Department of Geology, Lakehead University, 955 Oliver Road, Thunder Bay, Ontario P7B 5E1, Canada
}

\begin{abstract}
Pyrochlore-group minerals are relatively common accessory constituents of calcite carbonatite at the Oka Carbonatite Complex, Quebec. This complex is a member of the Cretaceous Monteregian petrological province, and consists predominantly of calcite carbonatite and feldspathoidal silicate rocks. Mineralogical studies of the complex have identified ceroan pyrochlore, ceriopyrochlore, uranoan pyrochlore, uranpyrochlore, thorian pyrochlore and "thoriopyrochlore" as occurring within the NIOCAN and Bond Zone deposits. At Oka, pyrochlore [general structural formula: $A_{16-x} B_{16} \mathrm{O}_{48}(\mathrm{O}, \mathrm{OH}, \mathrm{F})_{8-y}$ ] typically occurs as euhedral to subhedral crystals, rarely as aggregates and clusters. Back-scattered electron images, coupled with results of energy-dispersion analyses, reveal complex compositional zoning in pyrochlore, which reflects changes in magma composition during growth. Uranium-rich pyrochlore from Oka exhibits either strong zonation or is devoid of zoning. Large compositional variations were observed for the major oxides of the pyrochlore: $\mathrm{CaO}$ (ranging from 4.1 to $34.8 \mathrm{wt}$ \% oxide), $\mathrm{TiO}_{2}(2.3-40.4 \%), \mathrm{Nb}_{2} \mathrm{O}_{5}(20.1-$ $58.1 \%), \mathrm{ThO}_{2}(0.3-18.2 \%)$, and $\mathrm{UO}_{2}(0.1-28.0 \%)$. Ceriopyrochlore, ceroan pyrochlore and uranpyrochlore exhibit the greatest $A$-site vacancies, ranging from 8.1 to $62.5 \%$. Of the rare-earth elements, only Ce is present at high levels of concentration (ranging from 2.1 to $15.8 \% \mathrm{Ce}_{2} \mathrm{O}_{3}$ ). Of note is the significant content of $\mathrm{ZrO}_{2}$, which ranges from 0 to $16.3 \mathrm{wt}$.\%. An $A$-site substitution in the pyrochlore-group minerals has been identified between $(\mathrm{REE}+\mathrm{U}+\mathrm{Th})$ and $(\mathrm{Na}+\mathrm{Ca}$ ), as well as a $B$-site substitution between $(\mathrm{Nb}+\mathrm{Ti})$ and $\mathrm{Zr}$. The wide variety of pyrochlore-group minerals at Oka, coupled with their textural features, indicate that the Oka calcite carbonatite has an extremely complex evolutionary history. The pyrochlore-group minerals crystallized from two or more carbonatitic magmas, enriched in Nb, Ti, LREE, U, and Th. The calcite carbonatites of the NIOCAN and Bond Zone areas are hybrid rocks. No simple hypothesis can be devised to explain the significant concentrations of pyrochlore in particular samples of host rock. Enrichment in specific zones is dependent upon rheological factors rather than compositional controls.
\end{abstract}

Keywords: calcite carbonatite, pyrochlore-group minerals, magma mixing, Oka carbonatite complex, Quebec.

\section{SOMMAIRE}

Les minéraux du groupe du pyrochlore sont des phases accessoires assez répandues dans la carbonatite calcitique du complexe d'Oka, Québec. Ce complexe fait partie de la province pétrographique Montérégienne, d'âge crétacé, et contient surtout des venues de carbonatite à calcite et des roches silicatées à feldspathoïdes. Nous avons identifié le pyrochlore enrichi en cérium, le cériopyrochlore, le pyrochlore uranifère, l'uranpyrochlore, le pyrochlore thorifère et le "thoriopyrochlore" dans les gisement de NIOCAN et de la zone Bond. A Oka, le pyrochlore [formule structurale générale: $A_{16-x} B_{16} \mathrm{O}_{48}(\mathrm{O}, \mathrm{OH}, \mathrm{F})_{8-y}$ ] se présente généralement en cristaux idoimorphes ou subidiomorphes, et rarement en aggrégats ou regroupés. Les images d'électrons rétrodiffusés, considérées avec les résultats d'analyses en dispersion d'énergie, révèlent une zonation complexe de la composition du pyrochlore, qui témoigne de changements dans la composition du magma au cours de la croissance. Le pyrochlore uranifère à Oka fait preuve d'une forte zonation ou bien est dépourvu de zonation. De grandes variations en composition sont développées: $\mathrm{CaO}$ (entre 4.1 et $34.8 \%$ de l'oxyde, proportion pondérale), $\mathrm{TiO}_{2}(2.3-40.4 \%), \mathrm{Nb}_{2} \mathrm{O}_{5}(20.1-58.1 \%), \mathrm{ThO}_{2}(0.3-18.2 \%)$, et $\mathrm{UO}_{2}$ $(0.1-28.0 \%)$. Le cériopyrochlore, le pyrochlore riche en cérium, et l'uranpyrochlore font preuve de la plus grande proportion de lacunes au site $A$, entre 8.1 et $62.5 \%$. Parmi les terres rares (TR), seul le Ce est présent à un niveau de concentration élevé (entre 2.1 et $15.8 \% \mathrm{Ce}_{2} \mathrm{O}_{3}$ ). Nous signalons aussi la teneur importante du $\mathrm{ZrO}_{2}$, entre 0 et $16.3 \%$. Nous avons identifié une substitution au site $A$ dans les minéraux du groupe du pyrochlore, impliquant $(\mathrm{TR}+\mathrm{U}+\mathrm{Th})$ et $(\mathrm{Na}+\mathrm{Ca})$, de même qu'au site $B$, entre $(\mathrm{Nb}$ + Ti) et Zr. La grande variété de minéraux du groupe du pyrochlore à Oka, et leur développement textural, montrent que la carbonatite calcitique résulte d'une évolution extrêmement complexe. Ces minéraux ont cristallisé à partir d'au moins deux venues de magma carbonatitique, enrichies en $\mathrm{Nb}, \mathrm{Ti}$, terres rares légères, $\mathrm{U}$, et Th. Les carbonatites calcitiques des gisements NIOCAN et de la zone Bond sont en fait hybrides. Aucune hypothèse simple ne pourrait expliquer les concentrations importantes de minéraux du groupe du pyrochlore dans des échantillons particuliers des roches hôtes. Un enrichissement dans des zones spécifiques dépendrait plutôt de facteurs rhéologiques que de contrôles compositionnels.

(Traduit par la Rédaction)

Mots-clés: carbonatite calcitique, minéraux du groupe du pyrochlore, mélange de magmas, complexe d’Oka, Québec.

$\S \quad$ E-mail addresses: sehay@ualberta.ca, rmitchel@lakeheadu.ca 


\section{INTRODUCTION}

Pyrochlore is a common accessory mineral of carbonatites, and is a member of a group of cubic $(F d \overline{3} m) \mathrm{Nb}-\mathrm{Ta}-\mathrm{Ti}$ oxides with the general structural formula, $A_{16-x} B_{16} \mathrm{O}_{48}(\mathrm{O}, \mathrm{OH}, \mathrm{F})_{8-y} \bullet z \mathrm{H}_{2} \mathrm{O}$, where $x$ and $y$ are vacant sites in the unit cell, and $x, y$ and $z$ are nonrational. Pyrochlore structures are capable of accommodating a wide variety of cations. The $A$ sites can be occupied by $\mathrm{As}, \mathrm{Ba}, \mathrm{Bi}, \mathrm{Ca}, \mathrm{Cs}, \mathrm{K}, \mathrm{Mg}, \mathrm{Mn}, \mathrm{Na}, \mathrm{Pb}$, $\mathrm{REE}, \mathrm{Sb}, \mathrm{Sr}, \mathrm{Th}, \mathrm{U}$ and Y. The $B$-site atoms include $\mathrm{Nb}$, $\mathrm{Ta}, \mathrm{Ti}, \mathrm{V}, \mathrm{Al}, \mathrm{Si}, \mathrm{Fe}$, and Zr. Further classification within the pyrochlore subgroup depends on whether any of the $A$-site cations, other than $\mathrm{Na}$ or $\mathrm{Ca}$, exceeds 20 at. $\%$ of the total occupancy of the $A$ site (Hogarth 1989).

Here, we summarize the results of a detailed investigation of pyrochlore-group minerals from two $\mathrm{Nb}$-enriched zones at the Oka carbonatite complex, Quebec, Canada. Niocalite, pyrochlore- and perovskite-group minerals are relatively common $\mathrm{Nb}$-bearing accessories in the Oka rocks and, in particular, in the carbonatites. This work concentrates on the pyrochlore-group minerals as they are useful indicators of the degree of petrological evolution of alkaline rocks.

\section{Geological Setting}

The Oka carbonatite complex is located about 40 kilometers west of Montreal, Quebec, and is a member of the Monteregian petrological province. Here, Cretaceous (110 Ma, Shafiqullah et al. 1970) carbonatites and feldspathoid-bearing silicate rocks intrude the Precambrian basement rocks in what has been interpreted as a double-ring structure (Gold 1963, 1967, 1972; Fig. 1). The complex is not deformed or metamorphosed, and extends along the axis of the Beauharnois arch (a broad northwest-trending arch) in a roughly oval shape. The Oka complex is seven kilometers long by two and a half kilometers wide, and is elongate northwest-to-southeast. Gold $(1963,1967,1972)$ suggested that it is composed of four plutons in two intrusive centers (a "figure eight" plan). Three occurrences of $\mathrm{Nb}$ are found at the Oka complex, the St. Lawrence Columbium deposit, the Bond Zone deposit and the NIOCAN deposit (Fig. 1). This is the first mineralogical study completed on the recently located NIOCAN deposit. Previous data for pyrochlore-group minerals from the St. Lawrence Columbium deposit will be compared to the new data from the NIOCAN and Bond Zone deposits, to evaluate the paragenesis of the niobium mineralization.

\section{Analytical Methods}

Approximately 200 samples from the NIOCAN deposit and the Bond Zone deposit were collected from five different drill sites, with depths of the samples ranging from 10 to 500 meters.
All mineral compositions in the present work were identified using X-ray energy-dispersion spectrometry (EDS) at Lakehead University, Thunder Bay, Ontario. Compositions were determined using a JEOL 5900 scanning electron microscope equipped with a LINK ISIS analytical system incorporating a Super ATW Light Element Detector. Raw EDS spectra were acquired for 60-300 seconds (live time) with an accelerating voltage of $20 \mathrm{kV}$ and a beam current of $0.45 \mathrm{nA}$. The spectra were processed with the LINK ISIS SEMQUANT software, with full ZAF corrections applied. The following well-characterized natural standards were employed for analysis: loparite $(\mathrm{Na}, \mathrm{Nb}, \mathrm{La}$, $\mathrm{Ce}, \mathrm{Pr}, \mathrm{Nd})$, perovskite $(\mathrm{Ca}, \mathrm{Fe}, \mathrm{Ti})$, corundum (Al), orthoclase $(\mathrm{K})$, benitoite $(\mathrm{Ba})$, jadeite $(\mathrm{Si})$, metallic $\mathrm{Pb}$, $\mathrm{Ta}$, Th, and U. X-ray-diffraction methods were not used, as the pyrochlore-group minerals exhibit significant alteration and large differences in the intragranular composition. Back-scattered electron (BSE) images were acquired with the LINK ISIS-AUTOBEAM system using the JEOL 5900 scanning electron microscope. The images were given false colors using the LINK-ISIS SPEEDMAP software package. Although false, the colors are defined by relative contrast and brightness on the BSE images, and therefore reflect the average atomic number of individual phases.

\section{MineRALOGY}

\section{NIOCAN and Bond Zone deposits}

Petrographic analysis showed all of the samples studied are coarse-grained calcite carbonatite rocks, containing euhedral to subhedral oxide and silicate minerals in a hypidiomorphic matrix of calcite. The carbonatite consists mainly of calcite, apatite, and manganese-bearing magnetite, with monticellite, latrappite, pyrochlore, niobian perovskite, biotite, niocalite and zirconolite as accessory phases.

At the NIOCAN and Bond Zone, pyrochlore typically occurs as euhedral to subhedral crystals, more rarely as aggregates and clusters. Pyrochlore is present in amounts varying from 2 to $15 \mathrm{vol} . \%$, and in apatiterich bands, it approaches 25 vol.\%. BSE images, falsecolor imaging (Fig. 2), coupled with detailed analyses by microprobe, reveal common complex compositional zoning. A small percentage $(<10 \%)$ of the pyrochloregroup minerals are devoid of detectable zoning. The following criteria have been used to describe the types of zoning and alterations present (Hogarth et al. 2000): 1) Primary zonation: Crystals vary in composition, and may change systematically from core to rim. Crystals exhibit sharply defined narrow zones of compositional banding. 2) Low-temperature alteration: Crystals exhibit an irregular amount of discolored material at the crystal margin, and show bleached zones and microfractures. Discolored, turbid patches can be observed within the 
crystal. Commonly, significant $A$-site vacancy is present. 3) Metamictization: The leaching of $\mathrm{Na}$ and $\mathrm{Ca}$ generates a significant $A$-site vacancy, which can only be detected by electron microprobe. Crystals with $>10$ wt. $\% \mathrm{UO}_{2}$ or $\mathrm{ThO}_{2}$ commonly are metamict.

The NIOCAN and Bond Zone pyrochlore have been classified following Hogarth (1989), on the basis of the occupancy of the $A$ site. Samples containing $>20$ atomic percent (at. \%) of Th, Ce, and U have been identified, and are named by a prefix, and termed "thoriopyrochlore" [not approved by the IMA, but classified using the Hogarth (1989) method], ceriopyrochlore, and uranpyrochlore, respectively. Samples containing less than 20 at.\% are named thorian pyrochlore, ceroan pyrochlore, and uranoan pyrochlore, respectively. Ceroan pyrochlore and uranoan pyrochlore are the most commonly identified pyrochlore occurring together within the same section. No more than two different subgroups of pyrochlore were found together within one sample. Euhedral, subhedral and anhedral grains are found as either discrete grains or clustered together within samples of carbonatite. Other $\mathrm{Nb}$ minerals, such as niobian perovskite and niocalite, occur in association with pyrochlore grains at the NIOCAN and Bond Zone

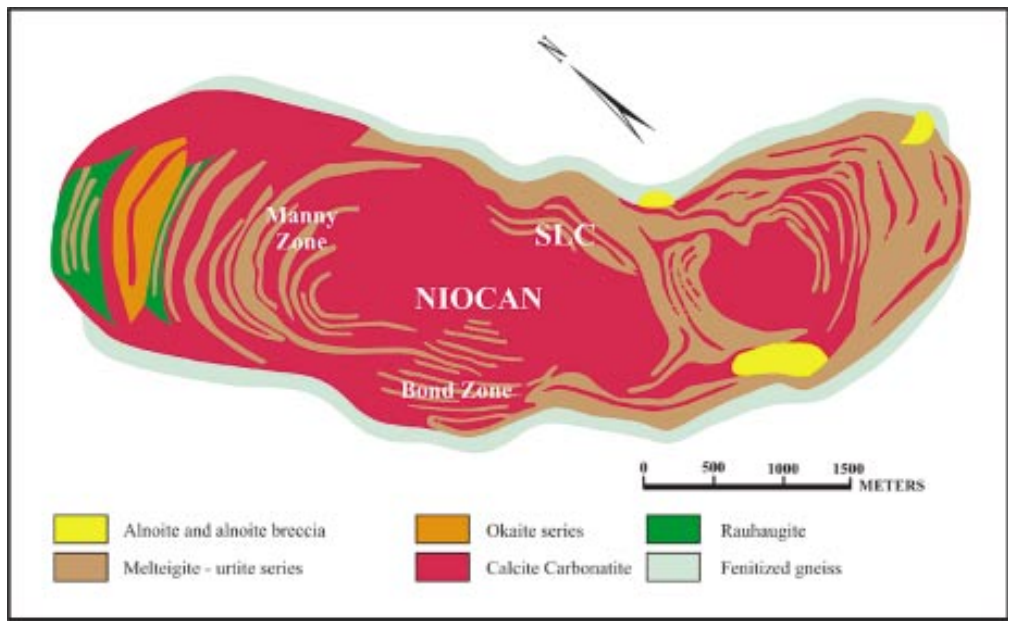

FIG. 1. Simplified geological map of the Oka pluton, modified from Gold $(1963,1972)$. Sample locations shown are: SLC (St. Lawrence Columbium), NIOCAN, and Bond Zone.
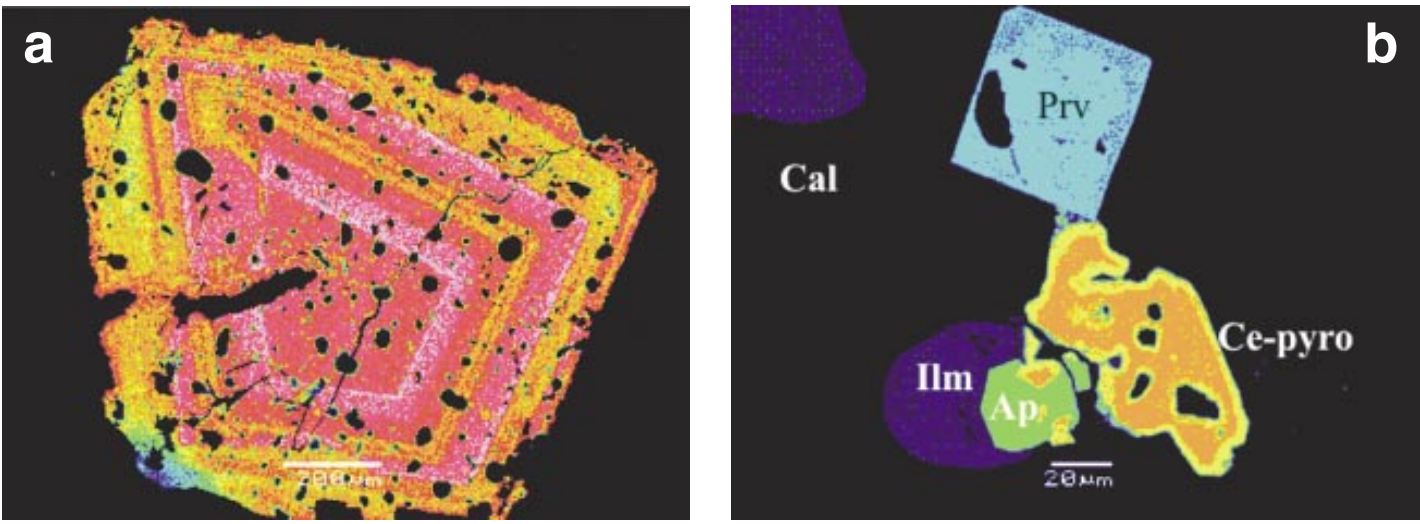

FIG. 2. Pyrochlore-group minerals from the NIOCAN and Bond Zone deposits (false color images). (a) Oscillatory-zoned uranoan pyrochlore, (b) two-zone ceroan pyrochlore in association with perovskite (Prv), apatite (Ap) and ilmenite (Ilm). 
deposits. In one example, niocalite was found as an overgrowth on ceroan pyrochlore, with euhedral niobian perovskite attached to the niocalite overgrowth (Fig. 3).

Uranoan pyrochlore is commonly found as metamict, mantled crystals, exhibiting primary zonation, patchy zonation and low-temperature alteration. Generally, it forms large $(1.0-1.5 \mathrm{~mm})$, intensely fractured grains. Uranoan pyrochlore is abundant within the NIOCAN and Bond Zone deposits, comprising about $2 \%$ of the modal abundance of the rock. Uranpyrochlore exhibits primary zonation, patchy zonation and lowtemperature alteration. Uranpyrochlore occurs in the NIOCAN and Bond Zone deposits as both intensely fractured discrete grains, and as clusters of smaller grains. Uranpyrochlore comprises about $1 \%$ of the modal abundance within the deposits.

Ceroan pyrochlore and ceriopyrochlore exhibit primary and patchy zonation. Bleached zones around microfractures and discolored, turbid patches can be seen in BSE images, and are interpreted as features of low-temperature alteration, as defined by Hogarth et al. (2000). They are typically found as small subhedral clusters $(0.1-0.22 \mathrm{~mm})$. The largest grains of ceroan pyrochlore $(\sim 1.4 \mathrm{~mm})$ contain apatite and calcite inclusions, and are intensely fractured. Ceroan pyrochlore is the most abundant of the pyrochlore-group minerals in the NIOCAN and Bond Zone deposits, comprising 9\% of the modal abundance (ceroan pyrochlore constitutes over $60 \%$ of all pyrochlore-group minerals in the Oka carbonatite complex). Ceriopyrochlore is not abundant within the NIOCAN and Bond Zone deposit, comprising approximately $0.3 \pm 0.1 \%$ of the modal abundance of the carbonatite.

Thorian pyrochlore rarely exhibits primary zonation, and is more commonly patchily zoned. Generally, thorian pyrochlore grains are small $(\sim 0.4 \mathrm{~mm})$ and subhedral. Both thorian pyrochlore and "thoriopyrochlore" are rare within the NIOCAN and Bond Zone deposits, altogether comprising about $0.2 \%$ of the modal proportion of the carbonatite. "Thoriopyrochlore" is found as small subhedral grains exhibiting patchy alteration. The grains of "thoriopyrochlore" and of thorian pyrochlore exhibit only small amounts of alteration.

\section{The St. Lawrence Columbium deposit}

Pyrochlore-group minerals have been previously described from the Bond Zone and the St. Lawrence Columbium deposits (Hogarth 1961, Perrault 1968, Petruk \& Owens 1975, Kalogeropoulos 1977, Chakhmouradian 1996). Petruk \& Owens (1975) studied eight separate grains of pyrochlore from the St. Lawrence Columbium deposit: three homogeneous grains, two zoned grains, two grains of uranoan pyrochlore, and one grain of uranpyrochlore. All grains studied showed only minor alteration and are euhedral to subhedral. Kalogeropoulos (1977) described the pyrochlore-group minerals at St. Lawrence Columbium as occurring as disseminated idiomorphic crystals and, more rarely, aggregates and clusters throughout the gangue, as well as intergrowths with calcite. Kalogeropoulos (1977) described the pyrochlore-group minerals as euhedral to subhedral (possibly metamict), exhibiting resorption textures, and containing numerous inclusions of calcite, apatite, and goethite (?). Pyrochlore-group minerals from St. Lawrence Columbium were reported as being typically present in amounts varying from 0.2 to about $5 \%$, with the exception of apatite-rich bands, where the modal abundance approaches $12 \%$ (Kalogeropoulos 1977).

\section{COMPOSITIONAL VARIATION}

\section{NIOCAN and Bond Zone deposits}

Compositional ranges have been determined from over 120 microprobe analyses of pyrochlore from the NIOCAN and Bond Zone deposits. Representative data are given in Table 1, for which the structural formulae have been calculated on the basis of two $B$-site cations. Extremely large compositional variations were observed for the major oxides: $\mathrm{CaO}$ (range 4.09-34.77 wt.\% oxide), $\mathrm{TiO}_{2}(2.28-40.36 \%), \mathrm{Nb}_{2} \mathrm{O}_{5}(20.09-58.12 \%)$, $\mathrm{ThO}_{2}(0.28-18.17 \%)$, and $\mathrm{UO}_{2}(0.1-27.98 \%)$.

Of the REE, only cerium is present at high levels of concentration, ranging from 2.08 to $15.75 \mathrm{wt} . \% \mathrm{Ce}_{2} \mathrm{O}_{3}$. Of note is the significant content of $\mathrm{ZrO}_{2}$, which ranges from 0 to $16.27 \%$. Low amounts of $\mathrm{SiO}_{2}(<4 \%)$ were found in the NIOCAN and Bond Zone pyrochlore-group minerals. They have an $A$-site vacancy ranging from 0 (completely filled) to $62.5 \%$ vacant. The pyrochloregroup minerals with increased amounts of REE (uranpyrochlore, ceriopyrochlore, and "thoriopyrochlore"), have lesser amounts of $(\mathrm{Na}+\mathrm{Ca})$ within their $A$ site, and define an $A$-site substitution (Fig. 4) (see below). Compositions plotting away from the main trend in Figure 4 represent relatively unaltered core compositions of ceriopyrochlore grains.

The proportions of $B$ cations $(\mathrm{Nb}, \mathrm{Ta}$, and $\mathrm{Ti}$ ) are illustrated in Figure 5. The NIOCAN and Bond Zone samples plot in the pyrochlore subgroup and have varying amounts of $\mathrm{Ti}$ and $\mathrm{Nb}$ at their $B$ site. They contain insignificant amounts of $\mathrm{Ta}\left(<2 \% \mathrm{Ta}_{2} \mathrm{O}_{5}\right)$, in common with pyrochlore-group minerals from most other calcite carbonatites (Nasraoui \& Bilal 2000). The bivariate plot $(\mathrm{Nb}+\mathrm{Ti})$ versus $(\mathrm{Zr})$ (in apfu; Fig. 6) shows a strong negative correlation, confirming the substitution of $\mathrm{Zr}$ for $(\mathrm{Nb}+\mathrm{Ti})$ at the $B$ site of the pyrochlore-group minerals from the NIOCAN and Bond Zone deposits.

Cation substitutions encountered in pyrochloregroup minerals from calcite carbonatites were discussed by Nasraoui \& Bilal (2000). Figure 7 is a planar vector representation of substitutions involving pyrochlore from calcite carbonatites taken from their work. Pyrochlore from the NIOCAN and Bond Zone deposits exhibits a large range in $\mathrm{Ti}, \mathrm{Na}$ and $\mathrm{REE}$ contents 
(Fig. 8). Therefore, any combination of the substitutions might have occurred with the pyrochlore-group minerals from the NIOCAN and Bond Zone deposits. The rare-earth elements could have been incorporated into the structure by a coupled substitution involving only the $A$-site cations, according to:

$$
\mathrm{Na}^{+}+\mathrm{REE}^{3+}=2 \mathrm{Ca}^{2+}
$$

With constant $\mathrm{Nb}$ and $\mathrm{Ti}$, the ceriopyrochlore end-member, $\mathrm{REE}_{0.5} \mathrm{Na}_{0.5} \mathrm{CaNb}_{2} \mathrm{O}_{6}(\mathrm{OH}, \mathrm{F})$ can be generated. The end-member (REE)NaTiNbO 6 (OH,F) can be generated by a coupled substitution involving the cations of both sites $A$ and $B$, where $\mathrm{Na}$ is constant, according to:

$$
\mathrm{REE}^{3+}+\mathrm{Ti}^{4+}=\mathrm{Ca}^{2+}+\mathrm{Nb}^{5+}
$$

With constant $\mathrm{Ca}$, the end-member $\mathrm{Ca}(\mathrm{REE}) \mathrm{Ti}_{2} \mathrm{O}_{6}$ $(\mathrm{OH}, \mathrm{F})$ can be generated by a coupled substitution according to:

$$
\mathrm{REE}^{3+}+2 \mathrm{Ti}^{4+}=\mathrm{Na}^{+}+2 \mathrm{Nb}^{5+}
$$

With the REE constant, another coupled substitution can be deduced from the previous substitutions [2] and [3], where the calciobetafite $\left[\mathrm{Ca}_{2} \mathrm{TiNbO}_{6}(\mathrm{OH}, \mathrm{F})\right]$ end-member is generated:

$$
\mathrm{Ca}^{2+}+\mathrm{Ti}^{4+}=\mathrm{Na}^{+}+\mathrm{Nb}^{5+}
$$

In the compositional diagram REE-Ti-Na (Fig. 8), pyrochlore compositions from the NIOCAN and Bond

\begin{tabular}{|c|c|c|c|c|c|c|c|c|c|c|c|c|c|c|c|c|}
\hline & A & B & $\mathrm{C}$ & $\mathrm{D}$ & E & $\mathrm{F}$ & G & $\mathrm{H}$ & I & $\mathrm{J}$ & $\mathrm{K}$ & $\mathrm{L}$ & M & $\mathrm{N}$ & $\mathrm{O}$ & $\mathrm{P}$ \\
\hline $\mathrm{Na}_{2} \mathrm{O}$ wt.\% & 6.96 & 6.67 & 3.53 & 1.79 & 1.40 & 2.48 & 1.28 & 2.88 & & 0.79 & 1.46 & 1.53 & 2.27 & 5.05 & 3.66 & 3.17 \\
\hline $\mathrm{SiO}_{2}$ & 0.66 & & 0.89 & tr. & 1.36 & 1.75 & 1.36 & 2. & & 2.34 & 1.85 & 1.41 & 2.59 & 1.35 & 1.52 & 0.89 \\
\hline $\mathrm{CaO}$ & 17.26 & 17.01 & 11.46 & 10.17 & 17.02 & 15.67 & 17.61 & 14.89 & 7.22 & 15.74 & 17.28 & 16.26 & 16.54 & 24.76 & 12.74 & 15.40 \\
\hline $\begin{array}{l}\mathrm{TiO}_{2} \\
\mathrm{MnO} O\end{array}$ & 5.50 & 6.28 & $\begin{array}{l}4.21 \\
0.99\end{array}$ & $\begin{array}{l}2.15 \\
0.85\end{array}$ & 7.33 & 7.56 & 7.91 & 7.69 & 11.44 & 11.84 & 7.82 & 9.50 & 9.72 & 27.81 & $\begin{array}{c}11.06 \\
\text { tr. }\end{array}$ & 7.95 \\
\hline $\begin{array}{l}\mathrm{Fe}_{2} \mathrm{O}_{3} \\
\mathrm{SrO}\end{array}$ & tr. & & 2.70 & $\begin{array}{l}1.91 \\
\text { tr. }\end{array}$ & 2.24 & 2.13 & 1.89 & 1.91 & $\begin{array}{l}2.00 \\
2.25\end{array}$ & 2.23 & 1.83 & 1.90 & 1.69 & 5.62 & 0.71 & 1.39 \\
\hline $\mathrm{ZrO}_{2}$ & 1.66 & 6.09 & 6.25 & 16.27 & 9.60 & & 9.79 & & 5.41 & & 5.10 & 5.91 & 5.22 & & 2.87 & 4.21 \\
\hline $\begin{array}{l}\mathrm{Nb}_{2} \mathrm{O}_{5} \\
\mathrm{La}_{2} \mathrm{O}_{3}\end{array}$ & 64.74 & 61.46 & $\begin{array}{r}45.81 \\
1.24\end{array}$ & $\begin{array}{r}34.41 \\
1.25\end{array}$ & 36.79 & 43.28 & 35.13 & 41.43 & 34.60 & 37.62 & $\begin{array}{r}43.51 \\
1.46\end{array}$ & $\begin{array}{r}35.64 \\
1.35\end{array}$ & $\begin{array}{r}36.23 \\
0.84\end{array}$ & 27.59 & $\begin{array}{r}42.89 \\
2.44\end{array}$ & $\begin{array}{r}47.14 \\
1.77\end{array}$ \\
\hline $\mathrm{Ce}_{2}^{2} \mathrm{O}_{3}$ & 1.29 & 1.48 & 7.23 & 6.20 & 3.70 & 6.74 & 5.10 & 6.30 & 2.91 & 2.08 & 10.28 & 9.77 & 8.95 & 4.33 & 15.42 & 14.45 \\
\hline $\mathrm{Nd}_{2} \mathrm{O}_{3}$ & & & 2.00 & 2.27 & 0.86 & 0.83 & & 1.15 & & & 1.84 & 1.94 & 1.41 & 1.99 & 2.53 & 2.49 \\
\hline & & & tr. & tr. & & & & 2.3 & 3 & & & 6.48 & & & & \\
\hline $\mathrm{ThO}_{2}$ & 0.62 & & 12.42 & 21.05 & & 4.32 & & & & & 2.22 & 1.99 & 2.99 & & 1.81 & tr. \\
\hline $\mathrm{UO}_{2}$ & & & tr. & 0.51 & 20.5 & 12.48 & 20.90 & 16.26 & 24.46 & 27.98 & 2.92 & 6.37 & 5.91 & & 1.27 & tr. \\
\hline Sum & 98.69 & 98.99 & 98.73 & 98.831 & 100.80 & 97.241 & 100.97 & 97.81 & 96.66 & 99.72 & 97.57 & 100.05 & 94.36 & 98.50 & 98.92 & 98.86 \\
\hline a $a p$ & 0.774 & 0.729 & 0.459 & 0.261 & 0.182 & 0.336 & 0.169 & 0.378 & & 0.104 & 31 & 0.193 & 0.292 & 0.503 & 0.455 & 0.393 \\
\hline & 61 & 1.027 & 0.823 & 0.821 & 1.221 & 1.174 & 1.284 & 1.080 & 0.514 & 1.142 & 1.184 & 1.133 & 1.178 & 1.362 & 0.876 & 1.055 \\
\hline $\begin{array}{l}\mathrm{Mn} \\
\mathrm{Sr}\end{array}$ & & & 0.056 & 0.0 & & & & & 0.087 & & & & & & & \\
\hline $\mathrm{La}$ & & & 0.031 & 0.035 & & & & & & & 0.0 & 0.0 & 0.021 & & 0.0 & 0.0 \\
\hline $\mathrm{Ce}$ & 0.027 & 0.031 & 0.177 & 0.171 & 0.091 & 0.173 & 0.127 & 0.156 & 0.071 & 0.052 & 0.241 & 0.233 & 0.218 & 0.081 & 0.362 & 0.338 \\
\hline $\mathrm{Nd}$ & & & 0.048 & 0.061 & 0.02 & 0.021 & & 0.02 & & & & 0.045 & 0.033 & 0.036 & 0.058 & 0.057 \\
\hline Th & 0.008 & & 0.189 & 0.361 & & 0.069 & & & & & 0.032 & 0.029 & 0.045 & & 0.026 & \\
\hline $\mathrm{U}$ & & & & 0.009 & 0.305 & 0.194 & 0.317 & 0.245 & 0.361 & 0.422 & 0.042 & 0.092 & 0.087 & & 0.018 & \\
\hline$\Sigma A$ & 1.870 & 1.787 & 1.783 & 1.773 & 1.819 & 1.967 & 1.897 & 1.888 & 1.033 & 1.720 & 1.756 & 1.757 & 1.874 & 1.982 & 1.854 & 1.855 \\
\hline $\mathrm{Si}$ & 0.038 & & 0.060 & & 0.091 & 0 & 0.093 & 0.1 & & 0.159 & 0.1 & 0.092 & 0.172 & 0.069 & 0.098 & 0.057 \\
\hline $\mathrm{Ti}$ & 0.237 & 0.266 & 0.212 & 0.12 & & 0.3 & 0.405 & 0.392 & 0.571 & & & & & 1.073 & & 0.382 \\
\hline $\mathrm{Fe}$ & & & 0.136 & 0.108 & 0.113 & 0.112 & 0.097 & 0.097 & 0.100 & 0.114 & 0.088 & 0.093 & 0.085 & 0.217 & 0.034 & 0.067 \\
\hline $\mathrm{Zr}$ & 0.046 & 0.167 & 0.204 & 0.598 & 0.313 & & 0.325 & & 0.175 & & 0.159 & 0.187 & 0.169 & & 0.090 & 0.131 \\
\hline $\mathrm{Nb}$ & 1.679 & 1.566 & 1.388 & 1.172 & 1.114 & 1.368 & 1.081 & 1.268 & 1.039 & 1.125 & 1.258 & 1.048 & 1.088 & 0.640 & 1.245 & 1.363 \\
\hline$\Sigma B$ & 2.000 & 2.000 & 2.000 & 2.000 & 2.000 & 2.000 & 2.000 & $\begin{array}{l}0.043 \\
2.000\end{array}$ & $\begin{array}{l}0.15 \\
2.000\end{array}$ & 2.000 & 2.000 & $\begin{array}{l}0.115 \\
2.000\end{array}$ & 2.000 & 2.000 & 2.000 & 2.000 \\
\hline
\end{tabular}
Zone deposits are scattered, and show no definitive

TABLE 1. REPRESENTATIVE COMPOSITIONS OF PYROCHLORE-GROUP MINERALS FROM THE NIOCAN AND BOND ZONE DEPOSITS OF THE OKA CARBONATITE COMPLEX, QUEBEC

Total Fe expressed as $\mathrm{Fe}_{2} \mathrm{O}_{3}$. Samples were not analyzed for $\mathrm{F}$, but it is present. All data calculated on $2 B$-site cations. A,B: pyrochlore, $\mathrm{C}$ : thorian pyrochlore, D: "thoriopyrochlore", $\mathrm{E}, \mathrm{F}, \mathrm{G}, \mathrm{H}$ : uranoan pyrochlore, I,J: uranpyrochlore, $\mathrm{K}, \mathrm{L}, \mathrm{M}, \mathrm{N}$ : ceroan pyrochlore, $\mathrm{O}, \mathrm{P}$ : ceriopyrochlore. 


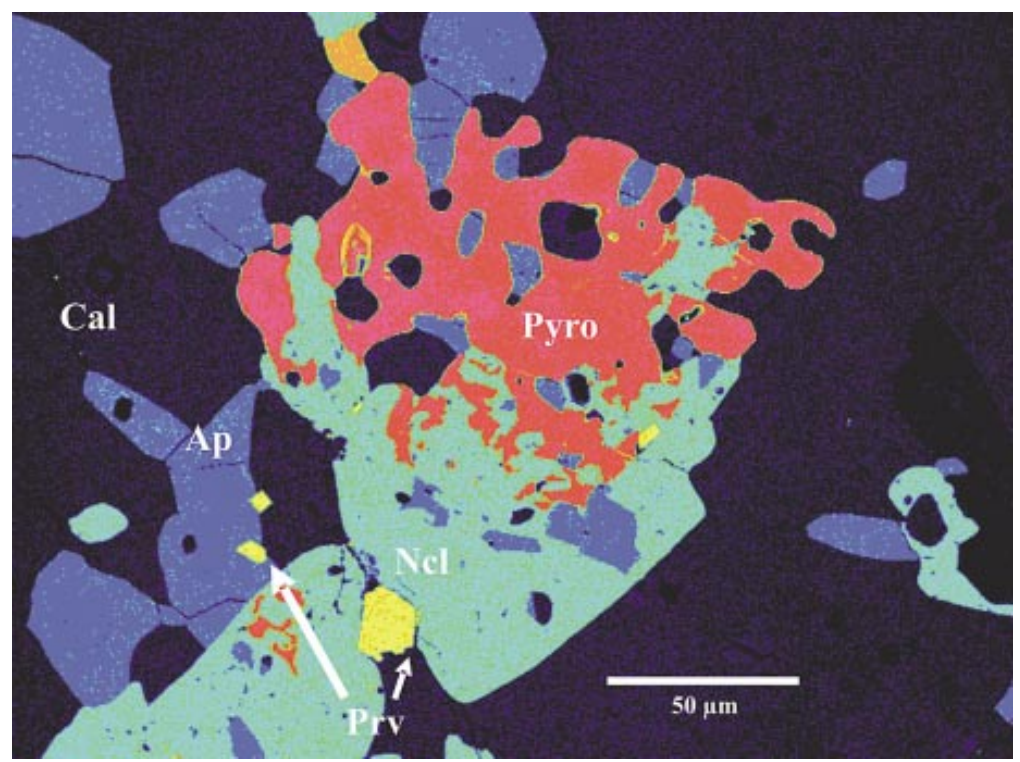

FIG. 3. False-color image of niocalite (Ncl) overgrowth on ceriopyrochlore (Pyro), coexisting with $\mathrm{Nb}$-rich perovskite (Prv). Cal: calcite, Ap: apatite.

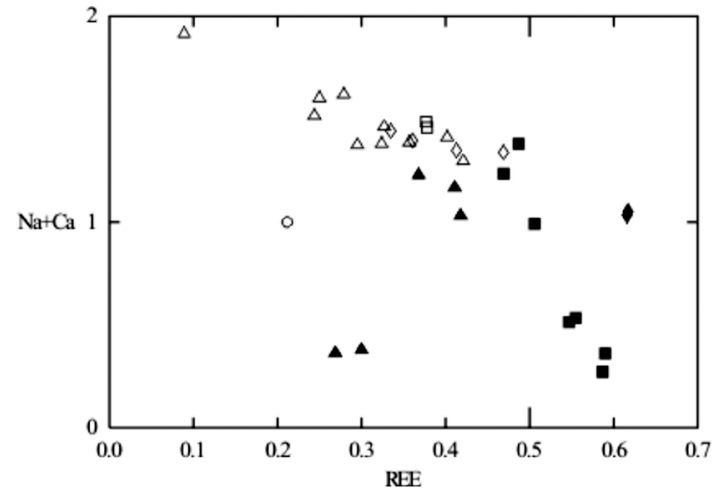

FIG. 4. Na +Ca (apfu) versus REE (apfu) for pyrochloregroup minerals from the NIOCAN and Bond Zone deposits. : "thoriopyrochlore", $\diamond$ : thorian pyrochlore,: uranpyrochlore, $\square$ : uranoan pyrochlore, $\boldsymbol{\Lambda}$ : ceriopyrochlore, $\triangle$ : ceroan pyrochlore. Representative compositions are shown for clarity.

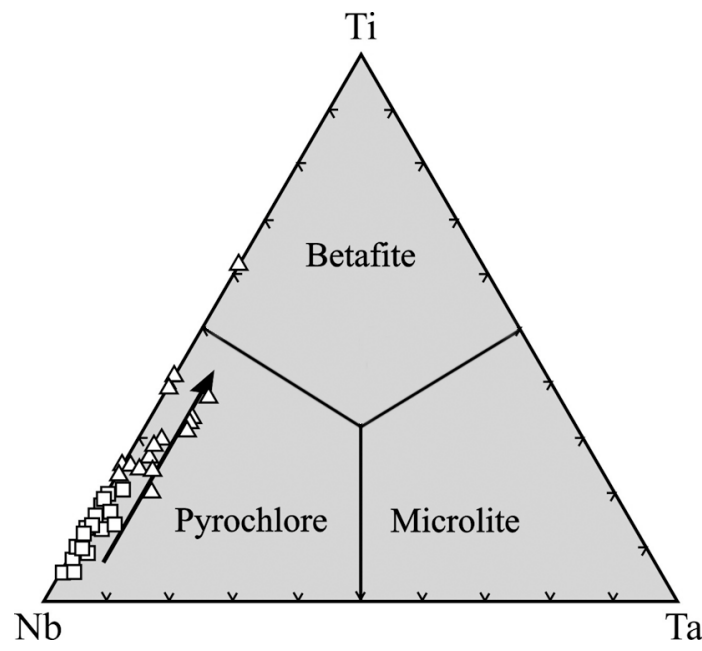

FIG. 5. Plot of elements at the $B$ position in the pyrochlore formula. Pyrochlore-group minerals from the St. Lawrence Columbium deposit (SLC) are represented by $\square$, those frome the NIOCAN and Bond Zone deposits are represented by $(\triangle)$. A proposed evolutionary trend is shown by the arrow. Representative compositions are shown for clarity. 


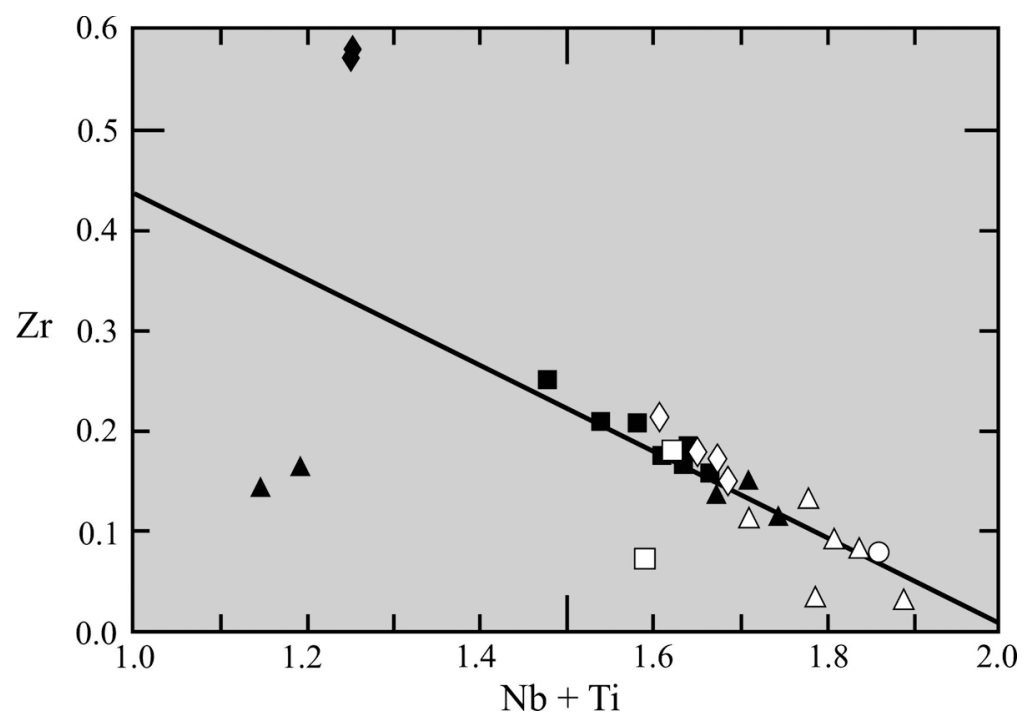

FIG. 6. $\mathrm{Zr}$ versus $(\mathrm{Nb}+\mathrm{Ti})(a p f u)$ for pyrochlore-group minerals from the NIOCAN and Bond Zone deposits: $\bullet$ : "thoriopyrochlore", $\diamond$ : thorian pyrochlore,: $\mathbf{\square}$ : uranpyrochlore, $\square$ : uranoan pyrochlore, $\boldsymbol{\Lambda}$ : ceriopyrochlore, $\triangle$ : ceroan pyrochlore. Representative compositions are shown for clarity.

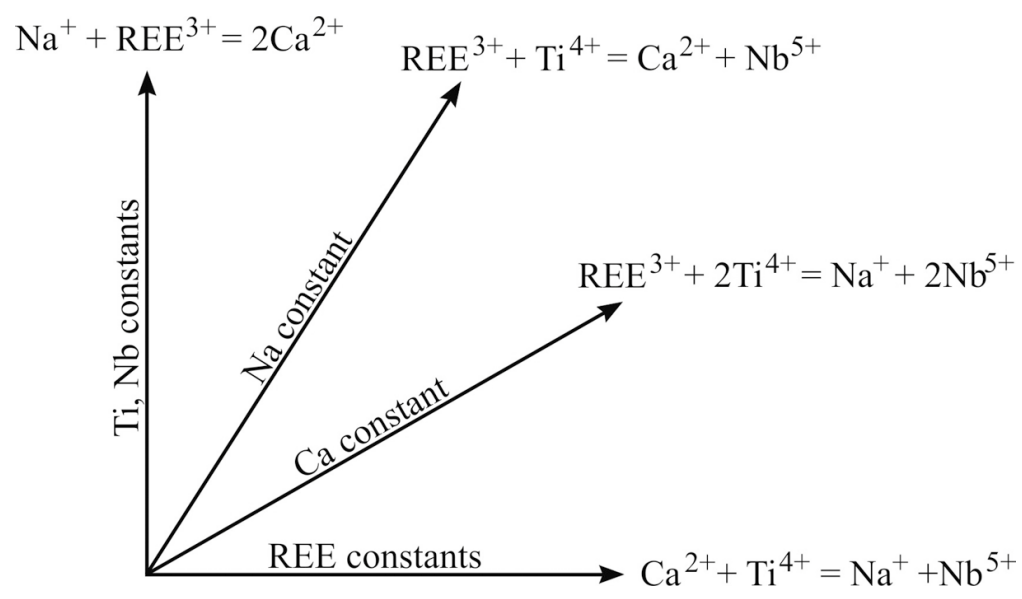

FIG. 7. Vector representation of substitutions involving pyrochlore-group minerals from calcite carbonatite (after Nasraoui \& Bilal 2000).

trends, indicating that any combination of the substitutions described above by Nasraoui \& Bilal (2000) may have taken place, with no particular substitution being dominant.

It is necessary to compare the compositional information with the textural information of the pyrochlore- group minerals from the NIOCAN and Bond Zone deposits at Oka. Lumpkin \& Ewing (1995) described alteration trends in pyrochlore from a range of parageneses and weathering environments. They identified three trends relating to "primary", "transitional", and "secondary" alteration, using triangular diagrams 
with apices corresponding to divalent $A$-site cations $\left(A^{2+}\right)$ filled by $\mathrm{Ca}, \mathrm{Sr}, \mathrm{Ba}, \mathrm{Pb}$ and $\mathrm{Fe}$, monovalent $A$-site cations $(A+)$ filled mainly by $\mathrm{Na}$ and $\mathrm{K}$, and $A$-site vacancies. Lumpkin \& Ewing (1995) reported that pyrochlore grains that display oscillatory zonation generally correspond to a "transitional trend", whereas pyrochlore grains that display patchy zonation generally correspond to an "alteration trend". Pyrochlore samples from this study were grouped according to their textures: oscillatory zoning, patchy zoning or absence of zoning. Textures of the NIOCAN and Bond Zone pyrochlore do not form "transitional" or "alteration" trends of the type described by Lumpkin \& Ewing (1995).

Some samples of uranoan pyrochlore exhibit distinct zoning on BSE images, but no corresponding compositional variation, or very little variation in the $\mathrm{UO}_{2}$ content across the grains. Both uranpyrochlore and uranoan pyrochlore have a small range of niobium and titanium (1.5-1.7 apfu) compared to that of the other pyrochloregroup minerals belonging to the NIOCAN and Bond Zone deposit. Moderately high concentrations of $\mathrm{Zr}$ occur, with up to $9 \% \mathrm{Zr}^{4+}$ present at the $B$ site of the uranoan pyrochlore, and up to $16.25 \% \mathrm{Zr}^{4+}$ present at the $B$ site of the uranpyrochlore.

Ceroan pyrochlore, along with ceriopyrochlore, exhibit the second largest $A$-site vacancies of the Oka pyrochlore-group minerals. Although the ceroan pyrochlore does not exhibit much variation within the $B$ site, a $B$-site substitution occurs between niobium and

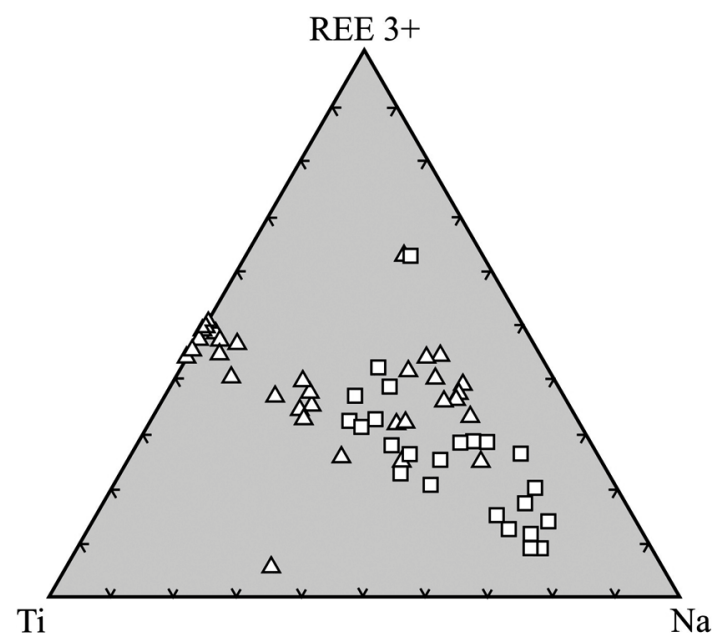

FIG. 8. A Ti $-\mathrm{REE}^{3+}-\mathrm{Na}$ plot of pyrochlore-group minerals from the St. Lawrence Columbium deposit (SLC) ( $\square$ ), and NIOCAN and Bond Zone deposits $(\triangle)$. Representative compositions are shown for clarity. titanium with zirconium (Fig. 6). Samples of ceroan pyrochlore have the lowest contents of zirconium of all the pyrochlore-group minerals from the Oka complex, averaging $3.9 \% \mathrm{Zr}^{4+}$ present at the $B$ site. Ceriopyrochlore grains have more moderate $\mathrm{Zr}^{4+}$ contents, averaging $4.4 \% \mathrm{Zr}^{4+}$ present at the $B$ site.

In contrast to other pyrochlore-group minerals from the NIOCAN and Bond Zone deposit, there is no significant intra- and intergrain compositional variation in the thorian pyrochlore. Thorian pyrochlore has higher $\mathrm{Zr}$ contents than the other pyrochlore-group minerals from the NIOCAN and Bond Zone, ranging from 7.3 to $10.65 \% \mathrm{Zr}^{4+}$ within the $B$ site. "Thoriopyrochlore" has the highest contents of $\mathrm{Zr}$ among the pyrochlore-group minerals, with up to $29 \% \mathrm{Zr}^{4+}$ at the $B$ site.

\section{St. Lawrence Columbium deposit}

The pyrochlore-group minerals identified in the St. Lawrence Columbium deposit are ceroan, uranoan and low-thorium pyrochlore (Petruk \& Owens 1975, Kalogeropoulos 1977). There are small compositional variations within the St. Lawrence Columbium pyrochlore; involving $\mathrm{CaO}$, in the range 14.17-18.78 wt. $\%$ oxide, $\mathrm{TiO}_{2}(2.12-8.45 \%), \mathrm{Nb}_{2} \mathrm{O}_{5}(49.21-$ $65.33 \%), \mathrm{ThO}_{2}(0-0.76 \%)$, and $\mathrm{UO}_{2}(0-8.82 \%)$.

The pyrochlore-group minerals at St. Lawrence Columbium have higher and less variable $\mathrm{Nb}$ contents compared to those from the NIOCAN and Bond Zone deposits. Therefore, the main constituent at the $B$ position of the pyrochlore-group formula is $\mathrm{Nb}$, with minor Ti-for-Nb substitution. Pyrochlore-group minerals at St. Lawrence Columbium have low amounts of $\mathrm{U}+\mathrm{Th}$, and a low $A$-site vacancy. An $A$-site substitution thus is absent, which corresponds to relatively unaltered pyrochlore. Pyrochlore-group minerals at the St. Lawrence Columbium deposit have very low $\mathrm{Zr}$ contents; therefore a $B$-site substitution involving $\mathrm{Zr}, \mathrm{Nb}$ and $\mathrm{Ti}$ is not evident.

\section{DisCUSSION}

Pyrochlore-group minerals at the NIOCAN and Bond Zone deposits have $A$ sites commonly occupied by $\mathrm{Ca}, \mathrm{Na}, \mathrm{REE}$, Th and $\mathrm{U}$, and rarely by $\mathrm{Mn}, \mathrm{Sr}$ and $\mathrm{Ba}$. Their $B$ sites are commonly occupied by $\mathrm{Nb}, \mathrm{Ti}, \mathrm{Fe}$, and $\mathrm{Zr}$, and less commonly by $\mathrm{Al}$ and $\mathrm{Si}$. Six different subgroups of pyrochlore-group minerals have been identified as occurring at Oka, and all can be found in the NIOCAN and Bond Zone deposit. The NIOCAN and Bond Zone pyrochlore belongs principally to the pyrochlore subgroup (Fig. 5). In many cases, the grains exhibit complex compositional zonation, reflecting changes in the fluid composition during crystal growth. Pyrochlore-group minerals at the NIOCAN and Bond Zone deposits show extremely large compositional variations, and represent the largest recorded variations of any pyrochlore hosted by calcite carbonatite. The 
extensive compositional variation is interpreted to result from the alteration of primary magmatic pyrochlore, and demonstrates that naturally occurring pyrochlore can tolerate an exceptionally high density of vacancies at the $A$ site. Nasraoui \& Bilal (2000) have described the different stages of alteration of pyrochlore-group minerals from the Lueshe carbonatite complex. Magmatic pyrochlore is identified as occurring in the pyroxenite, calcite carbonatite, silicate xenoliths and syenite. Hydrothermally altered pyrochlore occurs in the hydrothermal veins within the complex, whereas supergene pyrochlore is found to accumulate within the lateritic profile of the complex (Fig. 9). Figure 9 illustrates the compositional fields of magmatic, hydrothermal and supergene pyrochlore from Lueshe, as defined from data presented by Nasraoui \& Bilal (2000). Pyrochlore-group minerals from the NIOCAN and Bond Zone plot in all three of the fields: magmatic, hydrothermal and supergene (Fig. 9), yet are derived from the same paragenesis. The Oka carbonatite complex has no hydrothermal veins, and there are no lateritic horizons present. Thus, the conclusions of Nasraoui \& Bilal (2000) have no general applicability to other complexes.

Although $\mathrm{Ce}$ is the dominant REE present in pyrochlore at Oka, high concentrations of $\mathrm{Zr}$ have been found in the NIOCAN and Bond Zone pyrochlore, and $\mathrm{Zr}$ minerals are commonly found in close proximity to the pyrochlore-group minerals. $A$-site incorporation of $\mathrm{U}, \mathrm{Ce}$, and Th with $\mathrm{Na}$ and $\mathrm{Ca}$ occurred. No particular substitution is dominant, and any combination of substitutions may have occurred. When comparing compositional data between the NIOCAN and Bond Zone pyrochlore, no trends are identified.

The paragenesis of pyrochlore-group minerals at the NIOCAN and Bond Zone deposits is interesting because of the range of compositions occurring within a single sample. Two or more compositional and textural varieties of pyrochlore can be found in very close proximity $(2-5 \mathrm{~mm})$ to each other, implying that they could not have crystallized together in their current host-rock. These pyrochlore-group minerals probably crystallized in another portion of the carbonatite, and are derived from different batches of magma, and were later mixed and transported to their final location.

The pyrochlore-group minerals at the St. Lawrence Columbium deposit have few $A$-site vacancies, perhaps corresponding to a limited degree of alteration. The $\mathrm{Nb}$ contents, compared to those of the NIOCAN and Bond Zone deposits, are slightly higher and less variable. Therefore, the main constituent at the $B$ position of the pyrochlore-group formula is $\mathrm{Nb}$, with a slight Ti-for$\mathrm{Nb}$ substitution.

At the St. Lawrence Columbium deposit, those minerals have a large range of $\mathrm{REE}^{3+}$ and $\mathrm{Na}$, and a small range of Ti. Therefore, the REE may have been incorporated into the pyrochlore structure by a coupled substitution involving only the $A$-site cations according to mechanism [1].
With constant $\mathrm{Nb}$ and $\mathrm{Ti}$, the ceriopyrochlore endmember, $\mathrm{REE}_{0.5} \mathrm{Na}_{0.5} \mathrm{CaNb}_{2} \mathrm{O}_{6}(\mathrm{OH}, \mathrm{F})$ can be generated (Nasraoui \& Bilal 2000).

In a comparison of the St. Lawrence Columbium material with the NIOCAN and Bond Zone pyrochloregroup minerals, many differences can be identified. It has a lower modal abundance in its host carbonatite (ranging from 0.2 to 5 vol.\%). It is found as both homogeneous and zoned grains, and less commonly shows signs of alteration. It is found as inclusions within apatite and calcite, and has inclusions of apatite and calcite. Pyrochlore-group minerals in the NIOCAN and Bond Zone deposits are less commonly found as inclusions in other minerals, and host inclusions of apatite, calcite, REE carbonates and zirconolite, i.e., a much more diverse suite of minerals.

Trends have been identified between the compositions of pyrochlore-group minerals at St. Lawrence Columbium and the NIOCAN and Bond Zone. The first trend is an increase in Ti from the St. Lawrence Columbium pyrochlore to the NIOCAN and Bond Zone pyrochlore (Fig. 8). The second involves an increase in REE from the St. Lawrence Columbium to the NIOCAN and Bond Zone pyrochlore (Fig. 8).

\section{Conclusions}

Niocalite, perovskite and pyrochlore are the three main Nb-minerals occurring at Oka. The textures and compositions of these $\mathrm{Nb}$-minerals suggest that they did not crystallize in equilibrium in their current host-rock. Crystallization of these minerals could not have been contemporaneous, as they could not have been liquidus

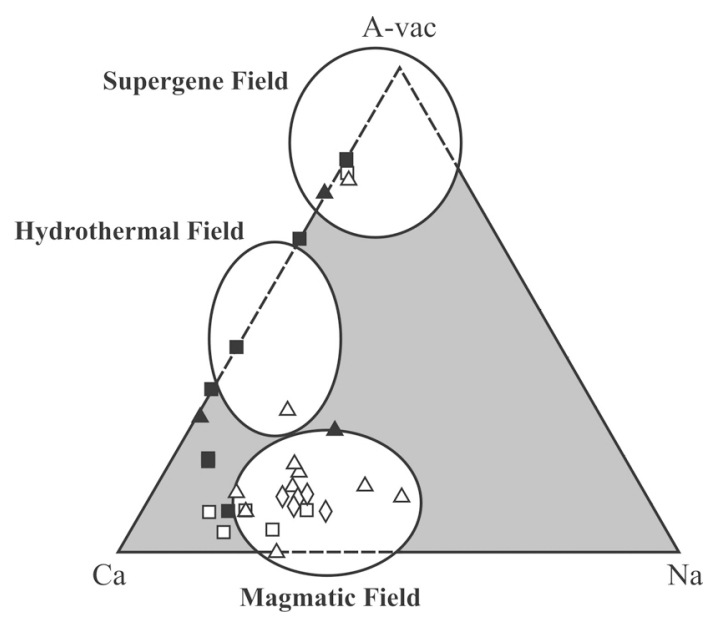

FIG. 9. A Ca $-\mathrm{Na}-{ }^{A} \square$ plot showing: "thoriopyrochlore" thorian pyrochlore $\diamond$, uranpyrochlore, uranoan pyrochlore $\square$, ceriopyrochlore $\boldsymbol{\Lambda}$, ceroan pyrochlore $\triangle$. Representative compositions are shown for clarity. 
phases at the same time. It is probable that the minerals were derived from other regions within the complex, possibly other magma chambers. These were disturbed, and their contents mixed with other batches of magma. Emplacement of this mixed assemblage produced their current host-rock.

The wide variety of pyrochlore-group minerals that have been identified throughout the Oka carbonatite complex also implies that the carbonatites formed from several batches of carbonatitic magma. Each batch, slightly different in composition, probably intruded the complex sequentially. Pauses in evolution, and possible mixing, coupled with changing intensive and extensive parameters, undoubtedly occurred. The changes in the evolution of the Oka carbonatites are reflected in the composition and textural variations shown by the $\mathrm{Nb}$ bearing minerals. The St. Lawrence Columbium pyrochlore appears to be from a relatively undifferentiated magma, rich in Ce and U. Compositional trends suggest that it is primary magmatic defect-type pyrochlore. The NIOCAN and Bond Zone pyrochlore may be the products of a more evolved magma. They have undergone significant compositional changes, and probably crystallized far from their final site of deposition; each stage of differentiation causing enrichment in one or more elements can crystallize a different pyrochlore-group mineral. The NIOCAN and Bond Zone pyrochlore-group minerals have undergone leaching of $A$-site cations such as $\mathrm{Na}$ and $\mathrm{Ca}$, with subsequent replacement with $\mathrm{Ce}, \mathrm{U}$, and $\mathrm{Th}$. Observed textures in the pyrochlore clearly support this hypothesis. The transport of the pyrochlore would subject them to changes in pressure and temperature and expose them to melts with different elemental compositions, therefore causing fracturing, mantling, metamictization, bleached zones and recrystallization.

The major conclusion of this work is that the calcite carbonatites at NIOCAN and Bond Zone are hybrid rocks. No simple hypothesis can be devised to explain the significant concentrations of pyrochlore in particular sections of host rock. Enrichment of specific zones in the pyrochlore is probably dependent upon rheological factors rather than compositional controls.

\section{ACKNOWLEDGEMENTS}

This study is supported by the Natural Sciences and Engineering Research Council of Canada. We gratefully acknowledge the help of Anne Hammond, Sam Spivak, and Al MacKenzie with sample presentation, technical help, and analytical work, respectively. We also thank NIOCAN Inc. for providing the samples used in the present study. This paper benefitted from the constructive comments of many helpful reviewers.

\section{REFERENCES}

Chakhmouradian, A.R. (1996): On the development of niobium and rare-earth minerals in monticellite-calcite carbonatite of the Oka complex, Quebec. Can Mineral. 34, 479-484.

GoLD, D.P. (1963): The Relationship Between the Limestones and the Alkaline Igneous Rocks of Oka and St. Hilaire, Quebec. Ph.D. thesis, McGill Univ., Montreal, Quebec.

(1967): Alkaline ultrabasic rocks in the Montreal area, Quebec. In Ultramafic and Related Rocks (P.J. Wylie, ed.). John Wiley and Sons, Inc., New York, N.Y. (288302).

(1972): The Monteregian Hills: ultra-alkaline rocks and the Oka carbonatite complex. Twenty-fourth International Geological Congress, Excursion Guidebook B-11, $1-47$.

Hogarth, D.D. (1961): A study of pyrochlore and betafite. Can. Mineral. 6, 610-633.

(1989): Pyrochlore, apatite and amphibole: distinctive minerals in carbonatite. In Carbonatites: Genesis and Evolution (K. Bell, ed.). Chapman and Hall, London, U.K. (105-148).

Williams, C.T. \& Jones, P. (2000): Primary zoning in pyrochlore group minerals from carbonatites. Mineral. Mag. 64, 683-697.

KALOGERopoulos, S.I. (1977): Geochemistry and Mineralogy of the St. Lawrence Pyrochlore Deposit, Oka, P.Q. M.Sc. thesis, Queen's Univ., Kingston, Ontario.

LuMPKIN, G.R. \& EwING, R.C. (1995): Geochemical alteration of pyrochlore group minerals: pyrochlore subgroup. $\mathrm{Am}$. Mineral. 80, 732-743.

Nasraoui, M. \& Bilal, E. (2000): Pyrochlores from the Lueshe carbonatite complex (Democratic Republic of Congo): a geochemical record of different alteration stages. J. Asian Earth Sci. 18, 237-251.

PerRault, G. (1968): La composition chimique et la structure cristalline du pyrochlore d'Oka, P.Q. Can. Mineral. 9, 383402.

Petruk, W. \& Owens, D. (1975): Electron microprobe analyses for pyrochlores from Oka, Quebec. Can. Mineral. 13, 282-285.

Shafiqullah, M., TuPPeR, W.M. \& Cole, T.J.S. (1970): K-Ar age of the carbonatite complex, Oka, Quebec. Can. Mineral. 10, 541-552.

Received September 13, 2003; revised manuscript accepted July 1, 2004. 